\title{
GEO TYRE TECHNOLOGY IN PAVEMENT STABILIZATION
}

\author{
Prof. Vithal H.Jadhav. \\ Civil Engineering Department \\ K.L.E Technological University, \\ Vidyanagar Hubballi, Karnataka (India)
}

\begin{abstract}
We are living in the era of challenging days. Every aspect of our day to day activities is a challenging one. Basic needs for human life are water, food, shelter and communication. Among these, in the development of society as a whole all over the world, the communication plays a vital role. Without the communication facility, the socio economic development is never possible.
\end{abstract}

The developments, sources, economy and environmental aspects are totally interrelated and interdependent. The day to day biggest problem all over the world is to control the environmental impacts. World is being bent up on mitigation, minimizing or compensating "Global Warming Issues". Without infrastructural developments there cannot be socio economic development and without environment impacts there may not be a development. So one has to think and challenge to develop the infrastructures by mitigating, compensating or optimizing environmental impacts.

Though we have several new soil stabilization techniques, for stabilizing pavement structure, the major grant allotted is being spent for the Sub grade/ Sub base improvement itself, in case of roads running in soft soil, B.C soil i.e., expansive soil and sandy soils. Even then the roads constructed with the present available stabilizing techniques on such soils have resulted in premature failure in several instances.

If we look at the road structure and it's functioning, the confinement plays a vital role in strengthening the road for resistance to its shear stress and lateral displacement, rather than using stabilization technique with only quality materials for construction. So far, the word confinement is not being much considered in road design aspects. However recently, uses of earth reinforcing techniques have come in to picture. Use of geo textile, Geo-synthetics, Geo-grid, Geo-fiber and Geo cells have thrown light in reinforcing the earth. Among these, Geo-cells have emphasized on cellular confinement of infill. But due consideration is to be given for execution methodology with skilled labors. Otherwise it is also proved to be a failure item in many circumstances as experienced in practical fields due to improper methodology adopted locally. The Geo-cells were used on Mundagod-Ansi SH-46 in Dandeli town limits (Karnataka in India) in the reach from $\mathrm{km} \mathrm{76+000}$ to $80+060$. It is proven from the experience gained in this case study, due to the vertical instability of thin geo-cells during execution and non confinement of the road edges, have made the pavement to fail prematurely. It was inevitable to remove the entire geo-cells from the experimented reach of pavement and rebuild with conventional items of flexible pavement including the construction of longitudinal sides R.C.C drains.
The confinement due to side longitudinal drains has kept the pavement intact at present.

But now the question in this aspect is whether the maximum stability and durability of road can be achieved by any other innovative, cost effective and eco friendly technique. In this regard it thought of using Geo Tyre stabilization technique using waste tyres by achieving cellular confinement.

The way in which the waste tyres are being disposed of by burning has become a health hazard and contributing to Global warming effects by emitting Carbon dioxide (CO2) \& Carbon monoxide (CO) (Photo 1).

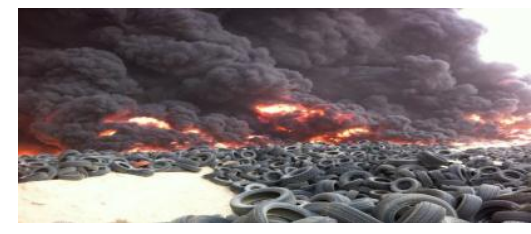

Photo1. Disposal of waste tyres by burning

The waste tyres are being disintegrated and the rubber (latex) is being used to produce CRMB (Crum Rubber Modified Bitumen) to use in pavement surface layer construction. But this also adds to environmental impacts and proved to be uneconomic also. Rubber granules are also used and experimented in concrete [5].Without such disintegration process the eco friendly disposal of waste tyres has also become a big problem.

The confinement of soil fill, as it is expected in case of geocells can easily be achieved to a greater extent with suitable technology using usual waste (raw) tyres without disintegrating them. On studies with KSRTC (Karnataka State Road Traffic Corporation) department alone in Karnataka (India), it is learnt that, nearly 180,000 waste tyres are to be disposed off every year.

Taking in to consideration of average size of heavy vehicles (Buses and Trucks) i.e., waste tyrs, it is computed that direct use of waste tyres with confinement technology, nearly $45 \mathrm{~km}$ length of "single lane" road can be strengthened every year. The length of improvement of roads with this geo-tyre technology using waste tyres in the state / country from all other sources is yet to be analyzed with a subject study in depth. This geo-tyre technology at an outset proves that it is cost effective, eco-friendly and speedy construction. However efforts are being made to execute this geo-tyre technology on an experimental base, for a stretch of any one road running in 
soft soil/B.C.Soil/soft soil, to analyze the enhancement in suitability, durability and performance of this new innovative technology for future course of action. This can be one of the environmental solutions also to dispose of waste tyres.

The success of this technology will save several millions of rupees in road construction / rehabilitation as well as to minimize and mitigate environmental impacts by avoiding burning of tyres and also helps in speedy construction.

Keywords-Geo-Tyre; C.B.R; Geo-Cell; Confinement; Pavement Stabilization; Sub grade; Sub base; Environtal solution; Cost effective construction;

\section{INTRODUCTION}

Among the infrastructural developments, communication i.e., road construction is the major activity. Since ancient days, man is still trying for several innovations and improvements in road technology. But the basic challenge is still remaining to have cost effective, eco-friendly solutions especially on soft clay soils, B.C soils, Sandy soil, Silt soil, Peat soil, Chalk soil loamy soils etc., In road construction, the structural parts of road i.e., Sub grade, Sub base and base are the important components for achieving the stability and durability of road structure and to function during design life for the intended use.

The rapid increase in traffic intensity on roads has become almost indispensible in human life. At the same time we find tremendous change in climate due to Global warming on the earth. So, deterioration of roads by their age, increasing vehicular load and change in climatic condition has become an unavoidable phenomenon in day to day life. As the days pass on, all roads need rehabilitation. Rehabilitation of pavement is a major activity for all highway agencies and has several consequences on agency resources and traffic disruptions because of extensive and extended lane closures. The traffic volumes on the primary highway system, especially in urban areas, have seen tremendously being increasing which is leading to failures of highway pavements. The aging of the State highway system and other primary systems built long ago has resulted in the expenditure of a large portion of highway funds on pavement rehabilitation which does not use proper method and materials for rehabilitation and hence again fails. Efforts to develop techniques and procedures that will result in cost-effective and long-lasting pavement rehabilitation to serve the nation's highway system well into the 21 st century should be made.

There are several reasons due to which the pavements deteriorate. The reasons may be extreme climatic conditions, use of unsuitable materials, improper construction methodology, faulty design, and sudden deviation in traffic especially on new roads designed for lesser traffic without considering such deviation after its construction. Poor clayey sub grade results in the corrugation at the surface and increases unevenness. Poor drainage conditions especially during rainy seasons, force the water to enter in to the pavement from the sides as well as from the top surface etc. Thus the Sub grade deteriorates resulting in settlement of the crust and in turn the road surface gets undulations. Looking to the govt., activities in construction of roads, one of the main reasons for the failure of the road crust is paucity of funds. Insufficient fund allotted for the road improvements restricts for the provision of sufficient crust though the design warns, due to local pressures and to make the road just motorable condition as a temporary solution.

Hence there is need for the rehabilitation of the pavement which involves following steps.

1. Prioritization of pavements based on class of roads in need of rehabilitation, which incorporates monitoring activities to assess the functional and structural condition of pavements.

2. Development of feasible rehabilitation strategies.

3. Selection of the most cost-effective rehabilitation strategy given a set of constraints which may include reduced service life, life-cycle costs, and budgetary constraints.

4. Adequate analysis of performance of the rehabilitated pavements.

In government organizations, generally when any pavement fails, the department takes up its rehabilitation without digging into its nature of failure and also without analyzing the root cause of failure due to pressure from the Govt. to address the problem on war foot basis.. Hence an effort is required as a need of the day, to evaluate the root cause of the highway deterioration. So an attempt is made to study the Performance Evaluation of a Rehabilitated State Highway in Karnataka. Unless the root cause is analyzed and the reason for failure is studied, proper solution cannot be suggested for further rehabilitation without expecting the premature failures. Such studies definitely will help in taking not only corrective actions but also mainly a preventive action in rehabilitation of the pavements against their failures.

The increasing amount of waste tyres worldwide makes the disposition of tyres a relevant problem to be solved. In the previous years over three million tons of waste tyres were generated in the EU states [ETRA, 2006. Tyre Technology International - Trends in Tyre Recycling. http://www.etraeu.org]; most of them were disposed into landfills. Since the European Union Landfill Directive (EU Landfill, 1999) aims to significantly reduce the landfill disposal of waste tyres, the development of new markets for the tyres becomes fundamental [5]. In some research granulated rubber and steel recovered from waste tyres are used in concrete and to study the mechanical behavior of concrete. This composition has given satisfactory results obtained regarding the bond between recycled steel fibers and concrete; on the other hand compressive strength of concrete seems unaffected by the presence of fibers despite their irregular geometric properties. Finally, flexural tests furnished in some cases results comparable to those obtained when using ISF as concerns the post-cracking behavior [5].

The change in the strength of concrete with crumb rubber waste additives can be forecasted from exponential equations. These relationships enable to foresee the regularities of strength properties when a certain amount of crumb rubber of a certain size fraction is added to concrete. The obtained exponential equations show that concrete compressive, flexural and splitting tensile strengths decrease with increasing crumbed rubber additive amount. The testing has also shown 
that the addition of a small amount of crumbed rubber slightly increases (7\%) the tensile splitting strength [6].

With this back ground the question raised is why not waste tyres without granulating them cannot be used for cellular confinement in case of pavement stabilization as in case of using Geo Cells. Using waste tyres in this manner can definitely be an economic and eco-friendly solution in disposing of waste tyres and enhancing the stability and durability of pavement structure. Since the tyres are elastic, this proposal at present is for flexible pavements only.

\section{EASE OF USE:}

Complete specification and methodology for geo-tyre technology in pavement construction.

This innovative methodology can be implemented for both Sub grade stabilization and Sub base stabilization. Before framing the detailed technical specifications for the said innovative technology let me emphasize on the followings:

1. Technicality in the process,

2. Materials required and

3. The construction methodology.

1. Technical aspect: Roads constructed on B.C soil, soft soil and soft clay have shown premature failures. Since confinement plays a vital role in stabilization of the road foundation in B.C soil, soft and soft clay, the use of geo-cell i.e., cellular confinement came in to picture. Based on the experiment conducted on Mundagod Ansi Road SH-46 in Dandeli town of Karnataka it was proved that the stability could not be achieved by Geo-cell due to vertical insatiability of the Geo-cell walls, wrong methodology in execution and also weak sub grade soft soil with very low C.B.R. Ultimately the road under experimental stretch was failed. The simple mechanical stapling of geo-cell walls was also not stable. Therefore when waste tyres are being disposed of by burning and melting, an innovative idea of using waste tyres as cells for confinement is thought. It is a thought of joining the tyres either by fusion bond welding or with the stainless steel nut bolts and then using them as cells for confinement with proper methodology. When the tyres are capable of taking the load of more than 60 M.T, by laden trucks and buses just by the confinement of the air inside the tyres, why the tyres should not take such loads on road, by confining the sub grade or sub base materials. The only question is to how to fill the tyres with infill materials. This has been explained under the methodology section 3 below.

\section{Materials required:}

a. Waste tyres,

b. Rubber pad or cut tyres trips,

c. Stainless steel (non corrosive) $16 \mathrm{~mm}$ dia nut and bolts.

d. Infill materials viz. Sub grade soil / Granular Sub bade / any solid waste disposable material as the case may be.

e. Wet mix macadam, f. Primer coat

g. Bitumen binding layer i.e., Bituminous Macadam (B.M) / Dense Bituminous Macadam, (D.B.M).

h. Binding layer - Bituminous (80/100) Tack coat and

i. Wearing coat - Semi dense bituminous macadam (S.D.B.C) /

j. Bituminous Concrete (B.C)

\section{The Construction Methodology:}

\section{Preparation of non bituminous Sub grade / Sub base layers:}

The methodology is almost similar to the conventional flexible pavement construction. The important aspect is to study the C.B.R of sub grade soil and also the soil properties. If the C.B.R is very low up to $5 \%$ then the Geo-tyre technology shall be adopted for Sub grade confinement since ultimate load is transferred to Sub grade by layer theory in truncated cone form. The objective with the design of flexible pavement is to avoid the excessive flexing of any layer failure to achieve this failure will result in the over stressing of a layer which ultimately cause the layer to fail. In flexible pavement, the load distribution pattern changes as the strength of the individual layer is different.[4]. If the C.B.R is $6 \%$ and more, then the Geo-tyre technology may be adopted for the confinement of the sub base.

i) Sub grade confinement [2]: It is to be confirmed that the soil or natural ground or $500 \mathrm{~mm}$ below the sub grade in case of embankment is well consolidated and should have maximum dry density (M.D.D) greater than or equal to $1.52 \mathrm{~g} / \mathrm{cc}$ up to $3.0 \mathrm{~m}$ height embankment and $1.60 \mathrm{~g} / \mathrm{cc}$ in case of height more than $3.0 \mathrm{~m}$. Relative compaction shall be greater or equal to $95 \%$, F.S.I free swelling Index shall be less than 50\%, Liquid limit (L.L) shall be less than $70 \%$ and Plasticity index shall be less than $45 \%$. In conventional method it is recommended minimum C.B.R for Sub grade soil shall be 8 to 10\%. M.D.D. shall me more than or equal to $1.75 \mathrm{~g} / \mathrm{cc}$ and Relative compaction shall be more than or equal to $97 \%$. These values are recommended for the unconfined Sub grade soil. But in the said innovative idea of using Geo-cell the sub grade is being fully confined by the waste tyres, any infill material which is not satisfying the above recommendations (i.e., Soil with less than 8 C.B.R) can also be used.

Complete specification for construction of Sub grade using Geo Tyre: Excavation and preparation of natural ground by compaction, to the required line grade and camber to the required dry density and providing and laying horizontally, and laying approved waste tyres in rows and columns as per the lane width requirement to the required line, grade and camber, using tyres of uniform size, duly checked for their required tensile strength, joining tyres to tyres with fusion bond welding or Stainless steel nut and bolt technique using approved gauge and size of nut and bolts of $16 \mathrm{~mm}$ dia, joining the edges of tyres tangentially at the ends by the vertical rubber strips of minimum height that of tyres made up of waste tyres or any other rubber material with the required tensile strength, joining 
the edge of tyres tangentially with the same joining process stated above, filling the tyres with approved material i.e., soil or any other inferior material than the conventional sub grade as per MoRT \& H specification and around the tyres with Sub grade material conforming to the standard requirements as per MoRT \& $\mathrm{H}$ and consolidating at OMC to the required dry density of $97 \%$ including cost of all materials, labours and hire charges of machinery and all lead and lifts and incidental charges etc., complete as per the direction of engineer in charge.

ii) Sub base confinement construction using Geo Tyre: This layer is laid above the Sub grade either with the natural soil with required specifications as per MoRT\&H [1] or the embankment prepared over which the sub grade is prepared as per the standard requirements to act as drainage layer. In case of sub base layer, the conventional sub base is being provided and called as Granular Sub base or G.S.B having C.B.R more than or equal to $30 \%$ [1] and Relative compaction more than or equal to $98 \%$. But in this innovative Geo-cell confinement the waste tyres can be filled with any inferior material not conforming to the standards, but the space around and edges of the tyres shall be filled with G.S.B conforming to the standards to act as drainage layer as the drainage of percolated water in the pavement is very much essential to keep the pavement stable. So the edge vertical strips of rubber of tyre pieces shall be bore with holes not more than the smaller particles of G.S.B in order to allow the water to drain off and to keep the infill material i.e., G.S.B. intact.

Geo-tyre for Sub base for soils with good C.B.R: Preparing the sub grade as per the requirements of IRC:36-2010 [2] and Providing and laying horizontally, approved waste tyres in rows and columns as per the lane requirements to the required line, grade and camber, using tyres of uniform size, duly checked for their required tensile strength, over the prepared sub grade, joining tyres to tyres with fusion bond or Stainless steel nut and bolt technique using approved gauge and size of nut and bolts of $16 \mathrm{~mm}$ dia, joining the edges of tyres tangentially with the same joining process stated above, at the ends by the vertical rubber strips of minimum height of tyres made up of waste tyres or any other rubber material with the required tensile strength and make the holes of diameter not more than the small particle of G.S.B, @ $150 \mathrm{~mm} \mathrm{C} / \mathrm{c}$ in two rows in staggered in the vertical end strips to drain off the water from filled approved Granular sub base with the standard grade and mix as per MoRT \& H [1] in between the tyres at centre and at edges and filling with approved material i.e., soil or any other inferior approved material than the conventional sub grade or sub base material into the tyres and consolidated at $\mathrm{OMC}$ to the required dry density of $98 \%$ for in fill material and to the required density of GSB including cost of all materials, labours and hire charges of machinery and all lead and lifts and incidental charges etc., complete as per the direction of engineer in charge.

iii)y Preparation of non bituminous base course layer i.e., Wet Mix Macadam (WMM) Section 406 page 133 [1] and Bituminous binding layers like B.M Section 504.3.2 page 173 [1] /D.B.M section 505.4 Section 505.4 [1], then adhesive layers and wearing coat shall be laid as per the requirement in conventional ways Sections 505.4.5, 505.4.6 [1]. In view of explaining the entire process of Geo-cell technology, complete standard specifications for implementation of both for Sub grade and Sub base are prepared and stated below.

\section{CONSTRUCTION METHODOLOGY USING} GEO-TYRE.

i) Geo-tyre for Sub grade for soil, with low C.B.R (For loose / Expansive /Soft soils) : Excavation and preparation of natural ground by compaction, to the required line grade and camber to the required dry density not less than 97\% [2] and providing and laying horizontally, and laying approved waste tyres in rows and columns as per the lane width requirement to the required line, grade and camber, using tyres of uniform size, duly checked for their required tensile strength, joining tyres to tyres with fusion bond welding or Stainless steel nut and bolt technique using approved gauge and size of nut and bolts of 16 $\mathrm{mm}$ diameter, joining the edges of tyres tangentially at the ends by the vertical rubber strips of minimum height that of tyres made up of waste tyres or any other rubber material with the required tensile strength, joining the edge of tyres tangentially with the same joining process stated above, filling the tyres with approved material (photo 2) i.e., soil or any other inferior material than the conventional sub grade as per MoRT \& H specification and around the tyres with Sub grade material conforming to the standard requirements as per MoRT \& $\mathrm{H}$ and consolidating at OMC to the required dry density of $97 \%$ including cost of all materials, labours and hire charges of machinery and all lead and lifts and incidental charges etc., complete as per the direction of engineer in charge as shown in figure.

ii) Geo-tyre for Sub base for soils with good C.B.R: Preparing the sub grade as per the requirements of MoRT \& H [1] and Providing and laying horizontally, approved waste tyres in rows and columns as per the lane requirements to the required line, grade and camber, using tyres of uniform size, duly checked for their required tensile strength, over the prepared sub grade, joining tyres to tyres with fusion bond or Stainless steel nut and bolt technique using approved gauge and size of nut and bolts of $16 \mathrm{~mm}$ diameter, joining the edges of tyres tangentially with the same joining process stated above, at the ends by the vertical rubber strips of minimum height of tyres made up of waste tyres or any other rubber material with the required tensile strength and make the holes of dia not more than the small particle of G.S.B @ $150 \mathrm{~mm} \mathrm{C/c}$ in two rows in staggered in the vertical end strips to drain off the water from filled approved Granular sub base with the standard grade and mix as per MoRT \& $\mathrm{H}$ in between the tyres at centre and at edges and filling with approved material i.e., soil or any other inferior approved material than the conventional sub grade or sub base material into the tyres and consolidated at OMC to the required dry density of $98 \%$ for in fill material and to the required density of GSB including cost of all materials, labours and hire charges of machinery and all lead and lifts and incidental charges etc., complete as per the direction of engineer in charge. 


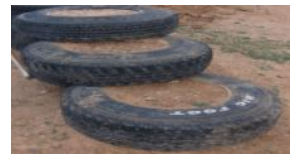

Photo 2. Tyres filled with Sub grade material

Sketch showing the arrangement of tyres, sub grade in tyres and G.S.B in between tyres for drainage is shown below:

Sub grade in fill material in tyres.

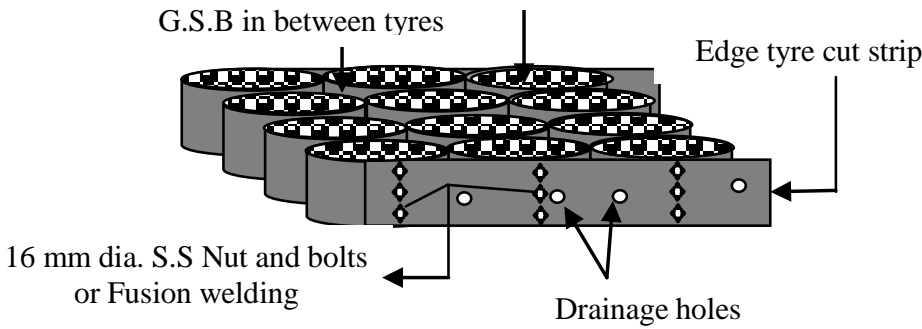

Figure showing the arrangement of Geo tyres using both Sub grade and G.S.B

\section{CONCLUSION:}

The following conclusions have been drawn from the present study:

1. The principle of cellular confinement can be easily achieved by using the waste tyres and stability and durability of the sub layers viz Sub grade and Sub base can be enhanced in construction of flexible pavement.

2. It is also concluded that by implementing the Geo Tyre technology for stabilization of pavement is the best eco friendly way of disposing waste tyres, which reduces environmental impacts to minimize the global warming.

\section{REFERENCES}

[1] Ministry of Road Transport \& Highways (MoRT \& H)(2013) Fifth Revision. Specifications for road and bridge works. Published by Indian Road Congress NEW DELHIINDIA (pp 109-111)

[2] Indian Road Congress:36 (IRC:36-2010) First RevisionRecommended practice for construction of earth embankments and subgrade for road works.(pp 3-20)

[3] Khanna S.K, Justo C.E.G. (2001) Eighth Edition, Published by Nem Chand \& Bros, Civil Lines Roorkee 247667 INDIA

[4] Adling Sharad S, Prof Gupta A.K, Dr. Magdum J.J ISSN2278

1684 PP 09-15. www.iosr.jornals.org. ISOR Journal of Mechanical and Civil Engineering. (IOSRJMCE) Published in Second International Conference on emerging trends in Engineering ( SICETE).
[5] Science Direct journals and books, (June 2009), Volume 29, Issue 6,(pp 1960-1970). Waste management.

[6] Grinys, Audrius, Sirilevicius, \& Dauksys Mandaugas (2012), Journal of Civil engineering \& Management. Tyre Rubber additive effect on concrete mixture strength. 